\title{
Expanding Opportunities for Applying Biomedical Innovations in Regional Economy
}

\author{
Oleg N. Shishatskiy* \\ Institute of Economics and Industrial Engineering \\ $S B R A S$ \\ 17 Academician Lavrentyev, Novosibirsk, \\ 630090, Russia
}

Received 19.05.2017, received in revised form 27.11.2017, accepted 06.12.2017

The article deals with the innovative development of the regional economy, the rationale for the economic viability of biomedical technologies, and the importance of their development in Krasnoyarsk. The work analyzes the prerequisites for a regional innovative biomedical cluster creation and identifies the necessary measures to support its effective development. To reduce the risks related to the development of new biomedical technologies it is proposed to use the approach recently adopted in developed countries, which is to perform evaluation at the early stages of a medical technology development. This approach will make it possible to forecast the demand for a new biomedical technology and the prospects for product sales in the market. If the evaluation results are negative, it becomes possible to abandon unprofitable projects or to change the development scenarios. The use of early assessment methods will optimize the development costs and increase the investment attractiveness of new biomedical technologies commercialization.

Keywords: early health technology assessment, biomedical cluster, investment attractiveness, medical technology development.

DOI: 10.17516/1997-1370-0195.

Research area: economics.

\section{Introduction}

Biomedical technologies (BMT) are developed to create products with certain diagnostic, therapeutic or preventive effects for their use in medical practice. BMT combine the products of biotechnological, pharmaceutical and medical industries.

These industries are of a special importance in the global economy. They are the most high- tech industries as per the volume of absolute and relative costs on scientific research and advanced development (R\&D). Providing the patients with access to modern medicines and supporting the public health care system stable development, these industries are also among the most socially significant ones.

The world market of pharmaceuticals and biotechnology is over 1 trillion dollars.

(c) Siberian Federal University. All rights reserved

* Corresponding author E-mail address: shishatskiy@mail.ru 
According to the forecast, in the period of 20162025 its growth rate will be $4.6 \%$, and by 2025 the market volume will reach 1.7 trillion dollars (Frost \& Sullivan..., 2017).

The analysts distinguish a number of factors that influence the market growth. The key ones, in our opinion, are demographic trends (population growth, aging, life expectancy growth), priority of human capital development and, correspondingly, increase in health care costs in developed and developing countries.

Russia's presence on the world markets of BMT is currently minor. The share of our country on these markets is less than $1 \%$. However, Russian pharmaceutical market is one of the most dynamic in the world. According to the DSM analytical company's data, the growth has averaged $11 \%$ over the past 5 years. The volume of the pharmaceutical market in Russia in 2015 exceeded 1 trillion rubles that is $9.3 \%$ higher than a year earlier. As per the Frost \& Sullivan company's estimates, the market volume will increase approximately twice in the course of a 9-year-period (from 694 billion rubles in 2011 to 1385 billion rubles in 2020) (Frost \& Sullivan..., 2017).
The share of domestic products is steadily growing year by year. As per the DSM analytical company's data, the share of Russian medicines grew by $4 \%$ in 2015 and made $27 \%$. The highest increase accounted for the high-cost innovative medicines: the share of domestic medicines increased from $13 \%$ in 2014 to $26 \%$ in 2015 (DSM group, 2016).

Russia lags significantly behind the developed countries as per such indicators as the costs on medicines and export volumes of pharmaceutical goods per capita. Compared to the nearest competitor country, our country's potential of pharmaceuticals consumption is at the minimum of 1.5 times (Fig. 1). The potential for export growth is much higher: to reach the level of Poland (as per the standardized indicator per capita at purchasing power parity (PPP)), the country has a potential for a 17 -fold increase of export, up to 9 billion dollars (Frost \& Sullivan..., 2017).

In recent years, innovative development of Russian economy has been a state priority. To achieve this purpose the government takes measures of general nature. It builds up innovative infrastructure, promotes innovative

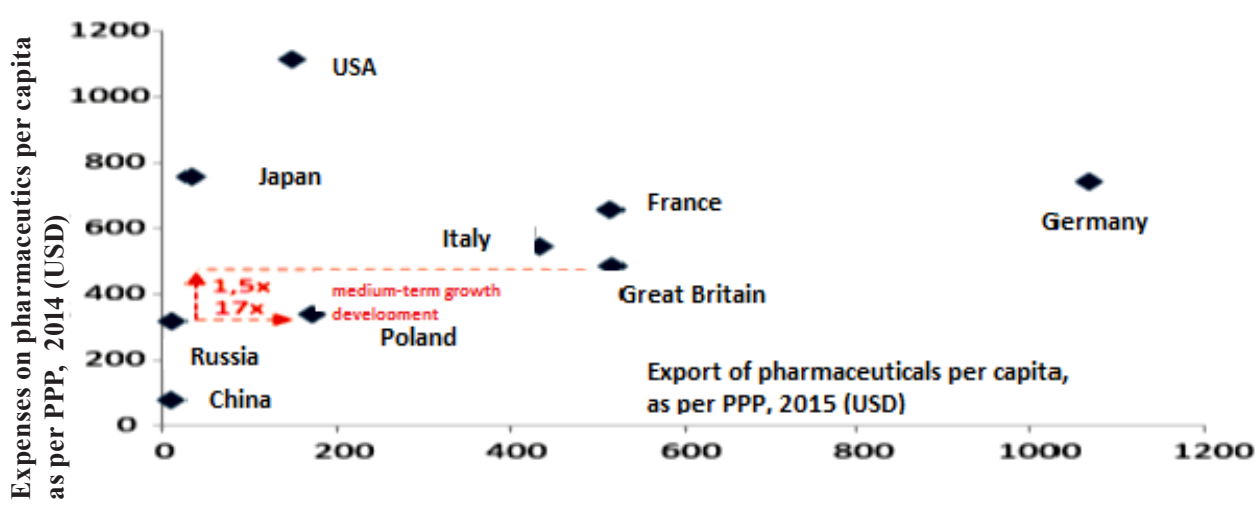

Note: data on the expenses on pharmaceuticals

in Japan and China in 2015

Source: OEC, Statista, ITA, ITC trade Map, Frost \& Sullivan analysis.

Fig. 1. Potential for the Russian pharmaceutical industry development 
clusters development, supports practically feasible companies, etc. Being an important trend of the country's innovative development, BMT has received a specialized support. The most important, in our opinion, are "Comprehensive Programme of Biotechnologies Development in the Russian Federation for the Period till 2020"; the Federal Target Programme "Development of Pharmaceutical and Medical Industries in the Russian Federation for the Period till 2020 and Further Perspective" as well as singling out the "HealthNet" market in the framework of the National technological initiative.

Creation of innovative medical products is carried out by the enterprises operating in the fields of BMT as well as by the scientific and educational organizations in the field of life sciences. Almost 2/3 of all new pharmaceuticals that appeared on the market in 2015 were initially developed at universities or start-ups and later licensed and purchased by large pharmaceutical companies (CIS GMP News, 2017). According to some experts, BMT may become one of the growth drivers in the regions of Russia.

\section{Prospects of the regional biomedical cluster development}

It is worth while considering the biomedical (BM) cluster formation in the city of Krasnoyarsk.

The world practice shows that these are advanced research centres performing fundamental and applied scientific researches in the field of life sciences that usually serve as the sources of BM clusters. These are leading universities (higher educational institutions) or research institutes (R\&D establishments) that are usually funded by the state.

The emergence of BM cluster is linked with the emergence of the first companies located near universities and research institutes, closely liaising and using common infrastructure. Efficiency of transfer and commercialization of technologies play an important role here. Start-up companies are financed by government support programmes, venture capital funds and individuals. A specialized infrastructure is needed for these enterprises development: incubators in the form of laboratory, production and office premises. These companies require services in accounting, legal and tax areas.

The next stage of the BM cluster formation is characterized by the increase in the number of specialized companies' departments due to the personnel availability and cost benefits. The first companies grow and the success stories appear, revealing new opportunities. The desires and hopes to repeat this success result in an increasing flow of talents and investments to the cluster. There appear new companies, suppliers of necessary products and services that cater for the emerging, growing companies and segments of large companies entering the cluster.

At this stage of the BM cluster development the need for laboratory and industrial premises will grow. So will the demand for the companies that carry out research on contracts (Contract Research Organizations - CROs) and contract manufacturing (Contract Manufacturing Organizations - CMOs).

The cluster growth contributes to the development and specialization of labour market with "horizontal" mobility of human resources (specialists' mobility between universities, research institutes and companies). As a result, experience and knowledge exchange will increase in the cluster.

Further, the cluster development turns to the organic growth when local universities and research institutes develop educational and research programmes favouring the cluster competitiveness. Specialization of infrastructure and system of suppliers get developed and grown. The number of cluster and infrastructure members will reach a critical mass that will improve the 
cluster's and its members' productivity and innovative activity.

Organic growth will make the cluster attractive for scientists and entrepreneurs in scientific, economic and cultural aspects. This will favour the involvement of large companies that have already firmly established themselves on the market and often can make the decision to transfer some of their own departments or research units or production facilities into the regions with the developed BM cluster.

\section{Prerequisites for the BM cluster formation and support for its development}

The possibility of the BM cluster formation in Krasnoyarsk is determined by the following prerequisites (factors).

Firstly, a significant amount of fundamental and applied research (R\&D) in the field of BMT is carried out in Krasnoyarsk. The research is conducted at the Institute of Biophysics of the Siberian Branch of the Russian Academy of Sciences, School of Fundamental Biology and Biotechnology of Siberian Federal University, Krasnoyarsk State Medical University. A number of these $R \& D$ has pioneering results which are published in representative journals and patented.

The "Biotechnologies of New Biomaterials" project of School of Fundamental Biology and Biotechnology of Siberian Federal University serves an example of a pioneering research in the field of BMT. The project focuses on the establishment of the Centre of biotechnological superiority and carries out fundamental research, educational and innovation activities in the field of biotechnology of new biomaterials.

Siberian Federal University manufactures biodegradable polymers of the polyhydroxyalkanoates (PHA) family and studies their properties within the framework of this project. One of the important areas of these biopolymers application is related to medicine, since these polymers have the properties of biodegradability and biocompatibility that makes them a promising biomaterial for manufacturing of innovative biomedical products and technologies. The fundamental possibility of obtaining various medical products from PHA have since been shown, the products being film coatings, retention suture, matrices and designs for tissue engineering, as well as prolonged drug delivery systems. The use of these products promises to improve the level of treatment and quality of patients' life in many fields, including cardiovascular surgery, orthopedics, urology, dentistry, etc. (Volova, 2014).

The second significant prerequisite for the BM cluster formation in Krasnoyarsk is availability of qualified personnel in the region. Apart from the researchers in scientific and educational organizations, the higher educational institutions of Krasnoyarsk (Siberian Federal University, Krasnoyarsk State Medical University, Siberian State Technological University, etc.) train qualified specialists. The cluster will need experts in different fields. These are researchers specializing in medicine, biotechnology, molecular biology and other scientific fields; physicians for preclinical and clinical trials; technical staff; experts in the field of biotechnological production processes; economists.

The BM cluster's successful development and activity in Krasnoyarsk will require support in the following areas.

The first area is the establishment of an effective process of new BM technologies (including scientific research, development, technology assessments and other stages) transfer and commercialization.

Centres of technologies transfer and commercialization functioning in universities and research institutes or established on the 
basis of several R\&D organizations will become elements of this process. These centres will help to patent developments, assess their perspective and relevance, and find funding for modification and further development of technologies and establishment of enterprises. They will also assist in other issues related to transfer of $R \& D$ results.

Another measure to support an innovation cluster development is availability of adequate (appropriate) financial resources. State funds and programmes are an important source of capital for an innovative cluster development. They are often established to overcome "market failures", i.e. to finance the stages of the transfer and commercialization process that have no other market sources.

Overall, the BM innovative cluster evolution will require a developed infrastructure of financing transfer and commercialization of promising developments, biomedical companies establishment and development. This infrastructure consists of individuals "angel investors", specialized private venture capital funds, state funds, stock market of high-tech companies and banking sector. State funds, specialized venture capital funds play an important role in the emergence and growth of new biomedical companies. This is the case with "angel investors", which must be located in the cluster proper, since their success requires personal contacts and personal acquaintance with the cluster' key players.

For the BM cluster development the participants will need accessible and quality infrastructure with incubators for young biomedical companies, premises for laboratory research and organization of the production. The use of mechanisms of public-private partnerships might be considered for infrastructure elements creation.

It is possible to start implementation of commercialization of the cluster's first projects, related to the use of biodegradable biopolymers
(PHA) as biomedical materials and the innovative BMT development, on the basis of infrastructure that is already accessible at Siberian Federal University and Institute of Biophysics of the Siberian Branch of the Russian Academy of Sciences.

Measures to stimulate the demand for the BM cluster innovative products as well as support of the cluster companies' export programmes will be also necessary for the BM cluster successful development.

\section{Risks reduction in the BMT development}

Innovative BMT development is a long, expensive process with significant risks (see Fig. 2). These risks are caused by the lack of information that may often lead to a wrong decision on choosing the projects and investments in the development of potentially inefficient medical products that have no call for in the society. Due to this there formed an overseas trend to assess biomedical technology at the early stages of its life cycle, the trend being termed the early health technology assessment (Musina, Omel'ianovskii, Krasheninnikov, 2016).

This trend is attributed to the sustained growth in expenditure on new biomedical technologies development. It explains the developers' interest in improving the development process efficiency and obtaining additional data to reduce "uncertainty" towards commercial demand while introducing new biomedical technologies to the market.

Attention is paid not only to forecasting the clinical (medical) efficiency of the technology. Assessment of its sustainability for inclusion in the purchasing and reimbursement programme is also made. Therefore, early assessment of BMT is carried out with the aim of informing a developer or an investor about the potential socio-economic value of the results of the BMT development 
project and possible ways of increase in economic efficiency of the development itself.

Early assessment of BMT is carried out at the early stages of researches. It has the following main areas of application.

1) decision-making during the technology development

- Preliminary market estimates on the basis of preclinical researches

At the stage of preclinical researches (in the course of the medical products prototype development) a pre-market assessment of BMT takes place. It implies the study of the course of a disease, target patient population, epidemiological factors, as well as related costs and therapies used to reflect the effects of diseases and establish therapeutic guidelines. Costs and effectiveness of available BMT are also assessed - the higher their cost effectiveness is, the greater the potential for a new cost-effective BMT creation is.

- Making the "continue/stop" decisions; selecting the potentially successful projects

The first available data obtained from phases I and II of clinical studies can be used for assessing commercial opportunities, establishing priorities in the development process and making the "continue/stop" decisions on the basis of information on whether a potential BMT can be developed further and then proceed to phase III of clinical studies. It makes sense to assess the BMT chances for economic success in advance for the reason that phase III of clinical studies is the most expensive.

It is very important to accurately determine potentially successful and unsuccessful projects. Early economic modeling contributes to more effective project portfolio management and investing in potentially successful projects.

- Development of the new BMT clinical studies design

Clinical and economic estimation helps to develop the design and protocols of clinical studies. This will improve the efficiency of the resource use. The key factors are choice of a comparator (a comparison drug), definition of outcomes important for a patient, methods of quality of life analysis. It is already in phase II of clinical studies that the tools and techniques can be applied to collect all the necessary information

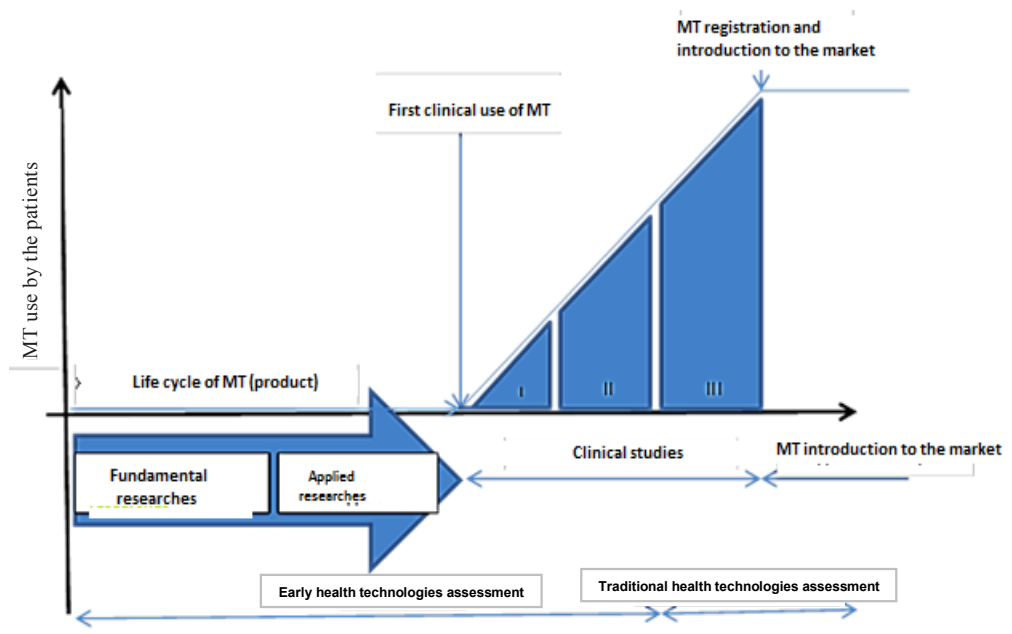

Fig. 2. Diagram of the BMT development 
and, thus, prove the economic advantages of the BMT under development.

2) justification of prices and reimbursement options

Pricing for the new BMT begins early in the course of its development. On the one hand, the future value of BMT for potential consumers and threshold of their willingness to pay should be taken into consideration, recognizing the consumers' preferences and integrating them into decisions made in the course of development. Cost-effectiveness analysis is used as a primary tool to determine the BMT value, the result being a ratio of additional value for the additionally obtained effect which corresponds to the willingness to pay. On the other hand, the developer needs to be confident that the BMT will generate sufficient income which usually ranges between the minimum requirements for return on investment and income from sales at the highest possible market price.

Early assessment makes it possible to forecast the volume of the new BMT market. In foreign countries the access of medical products to the market largely depends on their inclusion in the programmes of medical insurance and reimbursement which is based on the data of the BMT cost-effectiveness. So, if the assessment of BMT is positive and it is included in the programme of medical insurance and reimbursement, this significantly increases its sales volume that reaches higher values.

\section{Conclusion}

The author argues that early assessment of BMT will foster:

- the priority projects determination;

- new BM products development and commercialization;

- the increase of investment attractiveness of the BMT development projects.

Early assessment of BMT will make it possible to forecast the prospects for product sales on the market (BMT cost reimbursement, its inclusion in the restrictive lists). In case of negative assessment results there is a possibility to abandon non-profitable projects or change their development scenario (to change the formula, use or application, indications, positioning, prices, etc.).

Technology assessment at the early stages of their creation will make it possible to optimize the costs and increase the investment attractiveness of the BMT development.

\section{References}

"Denis Manturov otkryl kliuchevoi infrastrukturnyi ob’ekt Biofarmklastera "Severnyi" Biokorpus MFTI [Denis Manturov has Opened a Key Infrastructure Object of the Biopharmaceutical Cluster "Severnyi" ("Northern") - Biological Building of MIPT], In CIS GMP News, 2017, 1, 68-71.

DSM group (2016). [Analytical Report "Russian Pharmaceutical Market. Results of 2015". Available at: http://www.dsm.ru/docs/analytics/Annual_report2015_DSM_EN.pdf (accessed: 11 May 2017).

Frost \& Sullivan, RII Moskovskoi Birzhi, Fond razvitiia promyshlennosti [The Market of Innovations and Investments of Moscow Exchange, the Industry Development Fund] (2017). In Analiticheskii otchet "Obzor tendentsii na global'nom i rossiiskom farmatsevticheskom rynke [Analytical Report "The Overview of Trends in Global and Russian Pharmaceutical Market"]. Available at: http://fs.moex.com/files/14283 (accessed 11.05.2017).

Musina, N.Z., Omel'ianovskii, V.V., Krasheninnikova, A.V. (2016). Ranniaia otsenka - novyi podkhod povysheniia effektivnosti protsessa razrabotki meditsinskykh tekhnologii [Early Health 
Technologies Assessment - New Approach to improving the Efficiency of the Medical Technology Development Process], In PHARMACOECONOMICS. Modern Pharmacoeconomics and Pharmacoepidemiology, 9 (3), 53-59. DOI:10.17749/2070-4909.2016.9.3.053-059.

Volova, T.G. (2014). Sovremennye biomaterialy: mirovye trendy, mesto i rol' mikrobnykh poligidroksialkanoatov [Modern Biomaterials: World Trends, Place and Role of Microbial Polyhydroxyalkanoates]. In Sbornik "Mezhdunarodnaia nauchno-prakticheskaia konferentsiia "Biotekhnologiia i kachestvo zhizni" [International Scientific Conference "Biotechnology and Quality of Life": collection of articles], 504-505.

\title{
Расширение возможностей применения биомедицинских инноваций в экономике региона
}

\author{
О.Н. Шишацкий \\ Институт экономики и организации \\ промышленного производства СО РАН \\ Россия, 630090, Новосибирск, \\ пр. Академика Лаврентьева, 17
}

\begin{abstract}
Работа посвящена инновационному развитию экономики региона, обоснованию экономической перспективности биомедицинских технологий, актуальности их развития в городе Красноярске. В работе анализируются предпосылки создания регионального инновационного биомедицинского кластера и определены необходимые меры поддержки его эффективного развития. Для снижения рисков, связанных с разработкой новых биомедииинских технологий, предлагается применять недавно получивший распространение в развитых зарубежных странах подход, который заключается в проведении оценки на ранних этапах разработки медицинской технологии. Применение этого подхода позволит спрогнозировать востребованность новой биомедицинской технологии и перспективы продаж продукта на рынке. При получении негативных результатов оценки появляется возможность для отказа от неокупаемых проектов или для изменения сценариев их разработки. Применение методов ранней оценки оптимизирует расходы на разработку и повысит инвестиционную привлекательность коммерциализации новых биомедицинских технологий.
\end{abstract}

Ключевые слова: ранняя оценка медиинских технологий, биомедицинский кластер, инвестииионная привлекательность, разработка медицинских технологий.

Научная спещиальность: 08.00.00 - экономические науки. 